\title{
PEMBARUAN HUKUM ISLAM DALAM HUKUM KELUARGA DI INDONESIA
}

\section{Hilal Malarangan}

STAIN Datokarama Palu, Jl. Diponegoro 23 Palu e-mail: hilal.malarangan@gmail.com

\section{Abstract}

This article elaborates some aspects of reformation of the family law as the results of the ijtihâd of Indonesian experts. Nevertheless, not all of their legal thoughts are described in this article except for the family law material that has become the positive law in Indonesia. In elaborating those aspects of reformation of the family law, the author employs a comparative analysis and a culture social and judicial approach. Having conducted a comparative analysis the author found that there were -at least- 12 items of modifications and of reformation of the Islamic family law in the Indonesian family law, both in marriage, inheritance, will and bequest.

$$
\begin{aligned}
& \text { تبحث هذه المقالة في بعض تجديدأحكام الاحوال الثخصية كنتا ئج } \\
& \text { اجتهاد العلماء الا ندونسيين، بينما ليس كل منها تبحث في هذه المقالة } \\
& \text { الا ما قدأصبحت قانونا وضعيا بااند ونيسيا. في تبيين هذا الموضوع, } \\
& \text { يستخدم الكاتب تحليل المقارنة و مدخلي الاجتماعي والقانوني. فوجد } \\
& \text { الكا تبـــعلى الأقلـــانتى عشر تغييرا وتجديدا عندأحكام الاحوال } \\
& \text { الثخصية با ندونيسيا , سواء كانت فى الزواج, وفى الوراثة, و فى } \\
& \text { الوصية او فى الهيبة }
\end{aligned}
$$

Kata Kunci: pembaruan hukum, hukum keluarga Islam 


\section{PENDAHULUAN}

Al-Islâm Sâlih fî Kull Waqt wa Zamân! Ini prinsip, terbukti dan harus terus dibuktikan. Sumber primer hukum Islam (Alquran dan hadis) memayungi segalanya, tetapi tidak memuat segalanya. Sementara waktu terus bergulir membawa arus deras perubahan di segala bidang. Oleh karena itu, sebagaimana yang diinginkan oleh nass, para ahli (ulama dan fuqahâ') hendaknya terus memaksimalkan power of reasoning-nya untuk mencairkan dan mengalirkan hukumhukum Allah ke segala ruang dan waktu. Tidak ada alasan lain dari langkah ini kecuali didasarkan atas keinginan yang kuat untuk memperlihatkan watak hukum Islam sebagai hukum yang dinamis dan dapat memberikan solusi bagi masalah-masalah tersebut dalam konteks sosial yang berubah, tanpa mengabaikan prinsip-prinsipnya. Prinsip-prinsip yang dimaksud adalah tegaknya kemaslahatan, keadilan dan kesetaraan manusia. Kemaslahatan dan keadilan disepakati para ulama figh sebagai tujuan utama hukum Islam (maqâsid al-sharî'ah al-Islâmiyyah).

Keniscayaan perubahan hukum karena konteks sosial yang berubah, dalam sejarah pernah diberikan contohnya oleh 'Umar bin alKhat $\square \mathrm{t} \square$ âb untuk sejumlah kasus, termasuk terhadap teks yang jelas dan tegas, misalnya tentang al-t $\square$ alaq al-t $\square$ alâth (talak tiga). Demikian juga para sahabat yang lain dan Imam Syafi'i melalui qaul qadîm dan jadîd-nya. Perubahan hukum karena perubahan konteks sosial juga telah diberikan elaborasi secara cukup luas oleh Ibn alQayyîm al-Jauziyah, guru Ibn Kathîr dalam karya populernya A'lâm al-Muwaqqi'în. Dia membuat judul besar untuk uraian ini : "Taghayyur al-Fatwâ wa Ikhtilâfuha bi Hasâb Taghayyur al-Azminah wa al- Amkinah wa al-Ahwâl wa al-Niyyâh wa al-'Awâ'id"' (perubahan fatwa dan perbedaannya didasarkan pada pertimbangan perubahan waktu, tempat, kondisi sosial, motivasi dan kebiasaankebiasaan masyarakat). Maka adalah sulit bagi kita untuk mengatakan bahwa perubahanperubahan tersebut dapat dimaknai sebagai merubah atau mengganti hukum-hukum Tuhan. Sheykh Muh $\square \square$ ammad Must $\square$ afâ Shalabî dengan kritis menjawab persoalan ini. Dia. mengatakan :"Perubahan hukum sama sekali bukan berarti pembatalan (terhadap hukum-hukum Tuhan). Adalah tidak mungkin bagi siapa saja betapa pun kedudukannya dapat menyetujui pandangan tersebut. Perubahan tersebut sejatinya terjadi karena kondisi sosial yang 
berubah dan karena kemaslahatannya yang berganti. Hukum-hukum yang dibangun atas dasar kemaslahatan akan bergantung atas ada atau tidak adanya kemaslahatan itu. Apa yang terjadi adalah sebaliknya; langkah-langkah perubahan tersebut justru di dalam rangka menegakkan prinsip-prinsip syari'ah dalam situasi-situasi yang berubah (Muhammad, 2003:1).

Salah satu fenomena yang muncul di dunia Islam pada abad ke20 adalah adanya usaha pembaruan hukum keluarga di negara-negara berpenduduk mayoritas muslim. Turki misalnya, melakukannya pada tahun 1917, Mesir pada tahun 1920, Iran pada tahun 1930, Syiria 1953 pada tahun, Tunisia pada tahun 1956, Pakistan pada tahun 1961, dan Indonesia pada tahun 1974 (Muzdhar \& Khaeruddin, 2003:1).

Adapun bentuk pembaruan yang dilakukan berbeda antara satu negara dengan negara lainnya. Ada yang melakukan pembaruan berdasarkan taqnîn, ada yang berdasarkan putusan (dekrit) kepala negara (raja atau presiden), ada pula yang melakukannya dalam bentuk ketetapan-ketetapan hakim (Gupta, 1992:127). Sejumlah negara melakukan reformasi hukum keluarga secara komprehensif, sebagian lainnya melakukan secara parsial, bahkan ada negara yang melakukan pembaruan tahap demi tahap dari satu aturan tertentu secara sebagian, setelah komplit lalu dirumuskan lagi pembaruan di bidang hukum keluarga yang lain.

Tujuan dilakukannya reformasi hukum keluarga tersebut selain untuk merespons situasi dan kondisi "kekinian dan kedisinian", serta mengimplementasikan hasrat dan kepentingan rakyat berdasarkan nilai-nilai yang diyakini, juga untuk menciptakan unifikasi hukum, baik untuk keseluruhan rakyat tanpa memandang agama, atau untuk menyatukan dua aliran yang berbeda (Syi'ah dan Sunni di negara Iran dan Irak misalnya), atau menyatukan keragaman aliran dan mazhab seperti di Indonesia (Muzdhar, 2003:1).

Sebelum lahirnya UU No 1 Tahun 1974, belum ada keseragaman pedoman bagi para hakim dalam memutuskan hukum di bidang hukum keluarga. Para hakim peradilan agama masih menggunakan 13 kitab standar yang Syafi'i oriented dalam menyelesaikan suatu perkara keperdataan. Dampaknya adalah terjadi ketidakpastian hukum, karena dalam perkara yang sama di wilayah berbeda terdapat putusan yang berbeda pula akibat kitab yang digunakan berbeda. Namun dengan lahirnya UU No. I tahun 1974 
tersebut disusul dengan UU, Peraturan Pemerintah, Instruksi Presiden dan keputusan-keputusan yang lain, maka selain menjamin kepastian hukum, juga membawa arus reformasi dalam hukum keluarga di Indonesia.

\section{PENGERTIAN}

Secara sederhana yang dimaksud dengan hukum keluarga adalah hukum atau undang-undang yang mengatur perihal hubungan internal anggota keluarga dalam keluarga tertentu yang berhubungan dengan ihwal kekeluargaan. Secara lebih detail, Subekti menyatakan bahwa hukum keluarga adalah hukum yang mengatur perihal hubunganhubungan hukum yang timbul dari hubungan kekeluargaan, yaitu perkawinan serta hubungan dalam lapangan hukum kekayaan antara suami dan isteri, hubungan antara orang tua dan anak, perwalian dan curatele (Subekti, 1997:16).

Dalam literatur hukum Islam, hukum keluarga dikenal dengan istilah al-ahwâl al-shakhs $\square$ iyyah. Al-Ahwâl merupakan jamak dari alhâl yang berarti urusan atau keadaan. Sedang al-shakhs $\square$ iyyah berasal dari kata al-shakhs $\square$ yang berarti orang atau manusia. AlShakhs $\square$ iyyah itu sendiri berarti kepribadian atau jati diri (Rawwas, 1996:230).

Wahbah al-Zuhaylî memformulasikan al-ahwâl alshakhs $\square$ iyyah dengan hukum-hukum yang mengatur hubungan keluarga sejak terbentuknya hingga berakhirnya berupa, nikah, talak, nasab, nafkah dan kewarisan (Al-Zuhaylî, 1989:19).

Adapun yang dimaksud dengan hukum keluarga Islam adalah hukum Islam yang mengatur hubungan internal anggota sebuah keluarga muslim yang berkenaan dengan perkara munakahat, nafkah, pemeliharaan anak (hadânah) dan kewarisan. Tercakup dalam pemahaman ini adalah tentang wasiat dan hibah sebagaimana diatur dalam hukum keluarga di Indonesia.

\section{FAKTOR-FAKTOR PENYEBAB TERJADINYA PEMBARUAN HUKUM KELUARGA}

Pembaruan hukum Islam dalam berbagai aspek sudah terjadi dalam kurun waktu yang lama, berproses dengan kondisi dan situasi perkembangan zaman. Hal ini disebabkan karena hukum-hukum yang terkandung dalam kitab-kitab fikih klasik sudah tidak mampu lagi mengakomodir persoalan-persoalan baru yang berkembang. Dalam 
hukum keluarga, misalnya bagaimana mengatur distribusi harta waris kepada anak angkat (adopsi) atau orang tua angkat. Anak angkat dalam fikih klasik (berdasarkan nass) tidak berhak atas harta warisan. Demikian pula terhadap orang tua angkat. Letak keadilannya adalah anak angkat masih membutuhkan biaya pendidikan dan sebagainya; atau anak angkat tersebut telah memberikan kegembiraan, merawat dan sebagainya terhadap orang tua angkatnya. Tentu saja secara psikologis, sosiologis, dan ekonomis, wajar jika anak angkat mendapatkan bagian dari harta warisan. Fikih harus memberikan solusi atas persoalan ini.

Menurut para pakar hukum Islam Indonesia, pembaruan hukum Islam yang terjadi dewasa ini disebabkan oleh beberapa faktor antara lain: pertama, untuk mengisi kekosongan hukum karena norma-norms yang terdapat dalam kitab-kitab fikih tidak mengaturnya, sedangkan kebutuhan hukum masyarakat terus berkembang; kedua, pengaruh globalisasi ekonomi dan Iptek; ketiga, pengaruh reformasi di berbagai bidang yang memberikan peluang kepada hukum Islam untuk menjadi acuan dalam hukum nasional; dan keempat, pengaruh pembaruan pemikiran hukum Islam, baik oleh pakar hukum Islam manca negara maupun pakar hokum Islam nasional, terutama menyangkut perkembangan ilmu pengetahuan dan teknologi serta isu-isu gender (Mannan, 2006:154). Khusus tentang pembaruan hukum keluarga, termasuk di dalamnya adalah faktor unifikasi dan kodifikasi hukum keluarga Islam Indonesia (Abubakar, 1993).

\section{ASPEK-ASPEK PEMBARUAN HUKUM KELUARGA ISLAM DI INDONESIA}

Jika dicermati isi dan kandungan peraturan dan perundangundangan hukum keluarga Islam yang berlaku di Indonesia, akan ditemukan beragam aspek pembaruan dibandingkan dengan hukumhukum yang tercantum dalam kitab-kitab fikih klasik. Berikut ini dideskripsikan beberapa di antaranya yang penulis temukan.

\section{Bidang Perkawinan}

- Pencatatan Nikah

Dalam fikih klasik tidak ditemukan adanya keharusan pencatatan perkawinan, karena memang tidak menjadi rukun maupun syarat perkawinan. Namun dalam UU No 1 tahun 1974 jo. Pasal 10 PP 
No. 9 tahun 1975 dan pasal 5, 6 dan 7 KHI ditegaskan bahwa sebuah perkawinan harus tercatat oleh pegawai pencatat. Tujuannya adalah demi ketertiban administrasi.

- Cerai di Depan Sidang

Dalam fikih klasik hanya diatur masalah talak, fasakh, khul $\hat{u}^{\prime}$ dan lì'an, namun tidak ditegaskan bahwa keabsahannya harus di depan sidang pengadilan. Dalam KHI pasal 115 dinyatakan bahwa perceraian hanya dapat dilakukan di depan sidang Pengadilan Agama.

- Poligami

Dalam fikih klasik tidak ditemukan aturan bahwa poligami harus mendapat perizinan dari PA. Pasal $56 \mathrm{KHI}$ menegaskan bahwa poligami harus mendapat izin dari PA.

- Batasan Umur

Dalam fikih klasik hanya dipersyaratkan (dianjurkan) bagi mereka yang telah baligh. Dalam KHI pasal 15 jo.pasal 7 UU No. I tahun 1974 disebutkan bahwa batasan umur minimal 19 tahun bagi pria dan 16 tahun bagi wanita.

\section{- Nikah Hamil}

Dalam fikih klasik tidak ada ketentuan yang pasti (kontroversi) tentang nikah hamil. Dalam KHI pasal 53 ayat 1,2 dan 3 ditegaskan bahwa wanita hamil dapat dikawinkan dengan pria yang menghamilinya tanpa harus menunggu kelahiran sang anak, dan tak perlu nikah ulang pasca kelahiran itu.

- Kawin Beda Agama

Dalam fikih klasik dibenarkan kawin dengan ahlu al-kitab. Dalam pasal $44 \mathrm{KHI}$ ditegaskan pelarangan kawin beda agama.

- Harta Bersama

Dalam fikih klasik tidak dikenal (tidak diatur) tentang harta bersama. Dalam KHI pasal 85 sampai 97 serta PP No. 9 tahun 1975 pasal 24 dan 136 harta bersama, diatur dengan rinci dan lengkap.

- Wali

Dalam fikih klasik tidak diatur tentang wali adlâl dan penunjukan wali hakim. Dalam KH1 pasal 23 dan 24 ditegaskan 
masalah tersebut.

\section{Kewarisan dan Wasiat}

- Warisan bagi Anak atau Orang Tua Angkat

Dalam fikih klasik, anak angkat atau orang tua angkat tidak memiliki jalan untuk mendapatkan warisan. Dalam KHI pasal 209 ayat 1 dan 2 menegaskan bahwa orang tua angkat atau anak angkat berhak mendapat warisan melalui mekanisme was $\square$ iyat wâjibah. Was $\square$ iyat wâjibah ini pun tidak dikenal dalam fikih klasik.

- Ahli Waris Pengganti

Dalam fikih klasik tidak dikenal adanya ahli waris pengganti. Dalam KHI pasal 185 disebutkan bahwa, ahli waris yang meninggal lebih dahulu dari pewaris maka kedudukannya dapat digantikan oleh anaknya, kecuali anak tersebut melakukan pidana sebagaimana pasal 173.

- Musyawarah dalam Pembagian

Dalam fikih klasik telah diatur rincian bagian masing-masing ahli waris sesuai ketentuan nas $\square s \square$ dan dalil-dalil sekunder yang lain. Dalam KHI pasal 183 disebutkan bahwa para ahli waris dapat berunding dalam pembagian setelah mengetahui bagian masingmasing. Artinya, boleh jadi hukum 2:1 menjadi 1:1 karena adanya, kesepakatan di antara mereka.

- Ahli Waris Beda Agama

Dalam fikih klasik, dijelaskan bahwa salah satu sebab terhalangnya pembagian warisan jika ahli waris memeluk agama berbeda. Dalam KHI, menurut hemat penulis, ahli waris beda agama dapat saja menerima warisan, yang salah satu jalannya, melalui wasiat ataupun hibah. Tentunya melalui mekanisme yang diatur, yaitu tidak melebihi $1 / 3$ tanpa persetujuan ahli waris yang lain.

\section{PENUTUP}

Percepatan arus perubahan global dalam kehidupan masyarakat membawa implikasi yang serius di bidang hukum. Selalu ada keinginan yang kuat bagi masyarakat untuk mengimlementasikan nilai-nilai agama yang diyakini dalam lingkup sosialnya, termasuk di bidang hukum. Seiring dengan itu nilai-nilai tersebut harus mampu mengakomodir dan memberikan solusi atas persoalan persoalan kekinian dan kedisinian. Maka reformasi hukum menjadi sebuah 
kemestian.

Walaupun sedikit terlambat dibanding dengan negara mayoritas berpenduduk muslim yang lain karena berbagai faktor, para ulama dan pakar hukum Islam Indonesia telah mampu melahirkan Fikih Mazhab Negara Indonesia khususnya, di bidang hukum keluarga. Ijtih $\square \hat{a} d$ jamâ'î dari pakar hukum Islam Indonesia yang telah menjadi hukum positif tersebut sedikit banyaknya, memuat berbagai aspek pembaruan yang mampu mengakomodir dan memberikan solusi bagi kebutuhan hukum masyarakat yang sebelumnya tidak ditemukan atau ditegaskan dalam fikih-fikih klasik.

Namun demikian, kita tidak boleh menutup mata bahwa kemungkinan masih ada saja kekurangan dan kelemahan yang terdapat dalam hukum keluarga Islam Indonesia tersebut. Oleh karena, itu, sudah menjadi tugas bagi para akademisi dan praktisi hukum Islam Indonesia untuk mengkritisi dan mencarikan solusi demi perbaikan dan kebaikan bersama.

\section{DAFTAR PUSTAKA}

Abdul Mannar. 2006. Reformasi Hukum Islam di Indonesia. Jakarta: RajaGrafindo

Abubakar, Zainal Abidin. 1993. Kumpulan Peraturan Perundang-undangan dalam Lingkungan Peradilan Agama. Jakarta: Al-Hikmah.

al-Ahj, Muhammad Rawâsiq, at al. 1996. Mu'jam Lughah al-Fuqâhâ 'ArabîInklizî̀-Afransî. Bairut: Lubnan.

Anderson, JND. 1955. The Syrian Law of Personal Status. Bulletin in the School of Oriental and African Studies. (17).

Gupta, Kiran. 1992. Polygamy-Law Reform in Modern Muslim States: A Study in Comparative Law. Islamic and Comparative Law Review. xii (2) Summer.

Mahmood, Tahir. 1972. Family Law Reform in the Muslim World. New Delhi: The Indian Law Institute.

Muhammad, Husein. Pembaruan Hukum Keluarga Islam di Indonesia. http://www.fahmina.org/fi-id/index.php?option---comcontent\&task $=$ view \&id $=16 \&$ ltemid $=27$

Muzdhar, H.M. Atho \& Khaeruddin (Eds.). 2003. Hukum Keluarga di Dunia Islam Modern. Jakarta: Ciputat Press.

Subekti, 1991. Pokok-Pokok Hukum Perdata. Jakarta: PT. Intermasa.

al-Zuhaylî, Wahbah. 1989. Al-Fiqh al-Islâm wa Adillatuhu. Bairut: Dâr alFikr. 